\title{
Blow Out, Blow Back, Blow Up, Blow Off: The Plutonomic Politics of Economic Crisis since 2001
}

\author{
Timothy W. Luke
}

Two decades after the close of the Cold War, 2011 is an opportune time for reflections about the present and recent past. Twenty years ago as the Soviet Union was crumbling, Christopher Lasch asserted in The True and Only Heaven: Progress and Its Critics (1991), "it ought to be clear by now that neither fascism nor socialism represents the wave of the future. . . None of this means that the future will be safe for democracy, only that the danger to democracy comes less from totalitarian or collectivist movements abroad than from the erosion of its psychological, cultural, and spiritual foundations from within" (Lasch, 1991: 24). At the same time, Lasch fretted about the growing "revolt of the elites" in which he saw a powerful, prestigious, and a privileged new class of wealthy professionaltechnical experts--emerging all across the U.S.A. and other developed Western economies--increasingly were making themselves and their embedded institutional networks at the top 5, 10 or even 20 percent of society independent of public services, decaying cities, and civic activities in their nation states.

By 1995, Lasch argued with regard to the new class that "in effect, they have removed themselves from the common life. . Many of them have ceased to see themselves as Americans in any important sense, implicated in America's destiny for better or worse" (Lasch, 1995: 45). On the one hand, with the growth of "the borderless global economy, money has lost its links to nationality," and, on the other hand, the mobile, cosmopolitan, and self-centered new class increasingly had "little inclination to make sacrifices or to accept responsibility" as their denationalized businesses, professions, and skills followed their money into the liquid modernity of globalism in which "the cosmopolitanism of the favored few, because it is uninformed by the practice of citizenship turns out to be a higher form of parochialism" (Lasch, 1995: 46, 47). Being proponents of more material progress in 1991, the new class did not seem at all enamored with "a return to a more frugal existence: such views fell outside the progressive consensus" (Lasch, 1991: 529).

Things have changed, however, during the past two decades. The worried open acknowledgement of global climate change, excessive state borrowing, overextended public services, and rapid economic globalization have become secure articles of faith for many among this new class. Indeed, for their most successful factions among "the super-rich" (Brenner, 2002; Hacker and Pierson, 2010; and, Taibbi, 2010), there is a willing acceptance of frugality, impoverishment or dispossession, as long as these deprivations are endured by the many rather than them, while they affirm a renewed faith in the central importance of growing prosperity for the elite few (Kapur, Macleod, and Singh, 2005). These rhetorical concessions, then, are foundational principles among "the new global elite" (Freeland, 2011), which has become more evident in Lasch's "revolt" of talented and wealthy elites in richer and poor countries alike. This brief study of the U.S.A. in the twenty-first century examines aspects of the "more frugal existence" for the many, now known as "the 99 Percent" after the Occupy Wall Street occupation of Lower Manhattan's Zuccotti Park on September 17, 2011, created by continuous economic upheaval. It also probes the consolidation of greater wealth among the privileged and/or talented elites, who are now identified as "the One Percent" at the top of today's twirling economic booms and busts. From 1968 to 2009, income inequality between the richest Americans versus those at the poverty level almost doubled, this income inequality was the largest of all Western industrial economies, 
and it is becoming politically explosive (Leonard, 2010).

These inequalities have been developing for decades as key civic questions have failed to be addressed. With the fragmentation and then collapse of the U.S.S.R. in 1991, which perhaps became nearly inevitable with the suspension of the Cold War's initial conflicts over intensive ideological imperatives in 1969-1971 with the superpower détente between Moscow and Washington, or its subtle strategic shifts during 1979-1981 in response to the rise of radical Islam against secular modernism, one might ask if the foundational purposes of national power changed. As that long twilight struggle between dueling militant secular ideologies was followed in the 1990 s by the $24 \times 7$ trading cycles of multiple economic and cultural markets, did the central characteristics of the state change? Instead of asking what allows a nation-state to feel entitled to ask its citizens to be willing die for it (Foucault, 2007: 143), what happens when the citizenry now die to ask the nation-state to entitle them endlessly to individual prosperity, personal wealth, and safe employment? And, then, what happens as the state cannot deliver on those requests except for a favored few? It would appear that it leads to the creation, cultivation and consolidation of plutonomy.

\section{Blow Out: A Nation of NINJAs?}

There are many places to search for answers to these global questions on this terrain, but why not start at a very local level? In the wake of the Washington Mutual Bank's collapse in 2008, a class-action lawsuit against both WAMU's managers and owners turned up thousands of irregular, fraudulent, and predatory acts of commerce during the 2000s. One case can be cited as exemplary on all accounts. Soledad Aviles, a 57 year old Mexican immigrant, working as a glass cutter at $\$ 9$ an hour, was sold a $\$ 615,000$ house during 2006 in Orange County, CA. To meet his monthly payments, the bank's loan papers essentially required 96 percent of Aviles' net income (Fuentes, 2009: 12791280), and this requirement was made after his wife and three of his six daughters already had all agreed to service the mortgage with him. Moreover, this payment figure was itself incorrect, because his mortgage lender and real estate broker falsely reported the household's income at \$13,000 a month (Taibbi, 2010: 83).

Not speaking or reading English, Aviles signed these loan papers, which were full of hidden charges, obligating him to pay $\$ 4,800$ a month for the house instead of the $\$ 3,600$ he believed he and his family could cover (Fuentes 2009: 1280). Eager to move property, realize commissions, boost transaction fees or rack up high quick returns on resold closed deals, avaricious agents in the finance and housing industries from the retail to the wholesale level in the U.S.A. and abroad successfully created an apparatus in the 1990s and 2000s for the dispossession of labor, degradation of wealth, and destruction of autonomous producerism by blowing out all rational constraints on excessive consumer debt. This apparatus and its operations also made possible the role played by Soledad Aviles as a new type of civic, economic, and legal subject--the "no income, no job, no assets" (NINJA) mortgage borrower, house owner or wannabe entrepreneur at the core of the 21 st century's new "opportunity society."

"NINJA loans" became very ordinary commercial transactions between a financial lender and an alleged creditor. This creditor is "NINJA," because he or she has very little to no secure income, no certain job, no credible assets, but such commercial subjects were the most hotly pursued retail-level borrower during "liar loan" days in the U.S. housing bubble after September 11, 2001, when President Bush bid the nation to "go shopping" as a collective response to global terrorism. While many already are walling off those years as a bizarre aberrant cluster of characteristics, practices, and subjectivities that were exceptional moments in an extraordinary time of irrational exuberance and rampant fraud fostered by the lust for fast money, these maneuvers toward making such historical rationalizations are far too easy. In fact, the Aviles family is not exceptional, and the NINJA subject, in fact, may well be the new average consumer, basic individual or typical citizen of the present. Nearly a quarter of all house loans in the U.S.A. during 2011 were "underwater" with negative equity nationwide, but this figure in some areas runs as high as 65 percent in many states like Nevada, Florida, California or Arizona.

Living standards and income growth in the U.S.A. have stagnated in the four decades after 1973, following 25 years of steady spreading mass prosperity from 1948 to 1973. In the 1970s, this rising tide gradually ebbed. Today, the abject condition of NINJAhood, after a generation of electoral nostrums themed as "a Place called Hope," "Morning Again in America," or "the Opportunity Society," is where far too many people are left--totally broke, nearly insolvent, and frequently unemployed. Despite being residents of the last remaining superpower, a growing majority of people in the U.S.A. are increasingly trapped in the dead-ends of deskilling, underemployment, wagelessness, and assetlessness. 
When evaluating such transactions between WAMU and the Aviles family, too many experts and lay people dismiss them either as "experiences on the edge" or "borderline experiences which put into question what is usually considerable acceptable" (Foucault, 2007: 132) within the history of rational investment, organized commerce or modern capitalism. Yet, at the same time, one cannot fail to recognize how the pervasive such dealings were, or cynical ease with which such commerce spread, in the bubble economy of the 2000s. Those realities, in turn, should highlight many lines of contradiction "that are particularly fragile or sensitive at the present time" (Foucault, 2007: 137). Peeling away the distracting analyses and mystified appraisals of this incredible moment in American life, in turn, can add to "the history of actuality in the process of taking shape" (Foucault, 2007: 137). To evaluate the NINJA loan, and ask questions about how, why, where, and when the NINJAs have actually became so legion is to address two key questions for "a history of the present: "What are we and what are we today?" (Foucault, 2007: 136-137).

In considering the NINJA borrowing classes, then, one discovers "the new normal" in the Great Recession and its aftermath. Such extreme conditions of economic stagnation lead to an economic and social dead end where many people work flat out to evade just barely total poverty. This extreme normality, however, coexists with other exceptional developments. Looking at many of them together could help assemble an account of contemporary capitalist corruption, conflict, and chaos. At the same time, such considerations must be a "critique of what we are saying, thinking, and doing" as financial fantasias have spun up vast markets around bubble behaviors and logics, which now to some considerable extent define "a historical ontology of ourselves" (Foucault 2007: 13). What we are doing, thinking, and saying is soaked in the turbid political currents of the post-Cold War era's boom and bust cycles of bubble economics. The actuality caught taking shape here as "actually existing liberal capitalist democracy." Its essence has been marked by selling shoddy housing with inflated property prices to unqualified buyers in declining markets propped up by failing banks all supported by easy credit, fast money, heavily indebted national governments, and inexpensive oil.

Indeed, the sovereign debt of the U.S. has been one of leading causes of new worries at home and abroad. From 1960 to 2007, the U.S. government debt levels were on average about 36 percent. Yet, after twenty years of real estate bubbles across the U.S., eight years of war in Iraq and Afghanistan as well as the recent Great Recession, this ratio had soared to 62 percent at the end of 2010 (Kashkari and Rodosky, 2011: A15) as it continues to rise in 2011. During the coming decade, overall U.S. government debt could equal the nation's GDP by 2020, if not sooner, and thereby begin to stifle private lending, hobble future economic growth, increase borrowing costs, and undercut the dollar. A blowout in the national treasury's debt management strategies will only compound the economic challenges of the past five years. Ironically, it has been the bailout of many failed plutonomic interests in order to stabilize and salvage the surviving successful ones that lies behind this recent tremendous expansion in public debt issued by the central financial authorities in the U.S. since 2006. Nevertheless, this public debt burden gravely undercuts economic opportunities in many other credit markets as well.

\section{Blow Up: A Plutonomy?}

Amidst the frenzied bubbles of the 2000s, market analysts at Citigroup made a bold assertion: the world was dividing in virtually every country into two very different and quite divergent blocs. One bloc is "the rich," "the winners," or "the best" individuals prospering at the pinnacle of their businesses, professions, and societies. This bloc's emergence marks the advent of "the plutonomy," which has certain specific characteristics:

In a plutonomy there is no such animal as "the U.S. consumer" or "the U.K. consumer," or indeed the "Russian consumer." There are rich consumers, few in number, but disproportionate in the gigantic slice of income and consumption they take. There are the rest, the "non-rich," the multitudinous many, but only accounting for surprisingly small bites of the national pie (Kapur Macleod, and Singh, 2005: 2)

Most accounts of plutonomy highlight how "the Best," like Bill Gates, Jeff Bezos, or Steve Jobs, are making everyday life perhaps better for "the Rest." As the froth and foam of the stock market and real estate bubbles have burst, however, it is clear that plutonomic elites are not always rich because they are the best. Nonetheless, as they win, these elite meritocratic interests do tend to take most, if not all, that they can.

On the one hand, it is clear that today's ultra-rich are, by comparison to the Gilded Age or Edwardian Era, more 
commonly "the working rich." In 2004, 60 percent of the top 1 percent of Americans' income came from paid work (Freeland, 2011: 48). Still, on the other hand, the intrinsic merits or greater benefits of such increased hard work are not always necessarily good for anyone, but the plutonomic interests per se. The (re)naming of plutocracy, plutarchy, or simply predatory oligarchical elitism as "plutonomics" in commercial sociologies, like those written by the Citigroup analysts in 2005, is an attempt to naturalize, if not ratify, the development of incredible levels in overall income inequality and wealth both inside and outside of the U.S.A. Such sociologies reach back into time (Spain in the 1500s, Holland in the 1600s, America in the Gilded Age), and out across space (wealthy enclaves growing in Brazil, Russia, India, China as well as the Gulf States, Singapore or Brunei since 1973 or 1991), in their efforts to normalize the few instances in which plutonomic power prevails in society.

This wealth often can disappear in quick speculative bubbles, or it can multiply slowly in more cautious investment ventures, but plutonomy's profits rarely seem to trickle down in sufficient volume to enhance the well-being of more households beyond the top 10 percent of society. In 1988, the average American taxpayer's income was $\$ 33$,400. Adjusted for inflation in 2008, it actually dropped to $\$ 33,000$. At the same time, the richest 1 percent of American households, or those making $\$ 380,000$ annually in 2008 , have experienced nearly a 33 percent rise in their incomes [http://money.cnn.com/2011/2/16/news/economy/middle_class/index.htm?iid=EL].

In turn, the ratio of the income gained by the top 10 percent of Americans to the bottom 15 percent from 1968 to 2010 rose from 7.69 to 1 in 1968 to 14.5 to 1 in 2010 (Lind, 2010). At the same time, the top 5 percent of U.S. earners accounted for 35 percent of consumer spending, but the bottom 80 percent were only 39.5 percent of consumer outlays (Lind, 2010). This same lower 80 percent received only 50.6 percent of all income in 2010, while the top 20 percent took in 49.4 percent (Lind, 2010). Other surveys have found the share of total income going out to the top 1 percent of earners in 2007 was 23.5 percent; yet, the top 1 percent in 1976 took in only 8.9 percent of all income (Frank, 2010: B17). As income inequality has mushroomed since the 1960s, a generation-long trend in most countries that experienced relatively strong year-by-year increases for mass incomes after World War II stopped or slipped into reverse. Across the U.S.A. from 1945 to 1975, incomes rose about 3 percent a year; but, as they slowed, stagnated, and stopped rising, mass anxiety and individual distress about income inequality has grown apace (Frank, 2010: B17).

Plutonomy today, therefore, has also coincided with industrial and infrastructural disaccumulation. Whereas the Gilded Age of the 1800s in America rested upon new rapid and elaborate modes of industrialization, the rate of investment in new industrial technology, research, and plant has declined across the U.S.A. since the late 1970s. Of course, American firms still make these major investments, but they deploy them abroad with foreign partners at many other sites around the world. So the fastest growing sectors of the American economy since the Reagan era have been in finance, insurance, and real estate (FIRE) concerns, coordinating such economic globalization schemes. Disinvestment at home coupled with investment abroad have fed the growth of FIRE businesses along with the rising incomes of the skilled service sector workers from the new class global elites employed in advancing these pursuits. Without the Aviles family, and millions of others like them in the U.S.A., however, plutonomy for the new class elites would not have become so vibrant. Hence, the fine line between a plutonomy and a plutarchy or plutocracy is a fuzzy one, but the kinship between plutonomy and a kleptonomy is more evident as the proliferation of so many NINJAs show. Whether the robbed were the mortgagee or mortgagor, the specific retail borrower or vague wholesale flows of lendable monies, the local municipality coping with explosive land development or transnational funds of mobile capital in search of profit, plutonomy also has fostered both kleptocratic protectionism and kleptonomic triumphalism. Those who posed as "the best" did everything in their power to take advantage of "the rest" as well as not join their immiserated ranks. Hence, plutonomy thrives upon the NINJA subject, and NINJA subjects multiply because of plutonomics.

A plutonomy, then, is not necessarily rational or astute. During the 2007-2009 financial crisis, "by one measure, for about every $\$ 40$ in assets, the nation's five largest banks had only $\$ 1$ in capital to cover losses, meaning that a 3 percent drop in asset values could have wiped them out. The banks had their excessive leverage using derivatives, off-balance-sheet entities and other devices," according to the Financial Crisis Inquiry Commission (Chan, 2011: A1). "Best practices" were thrown out the window over the past generation as plutonomic interests worked every angle to serve their gains. As Lehman Brothers, Bear Sterns, and AIG discovered, such paths to plutonomic power proved disastrous for the new class experts managing these firms, the NINJAs they preyed upon, and the rest of the American economy. 


\section{Blow Back: This is the Best for the Rest?}

Remarkably, the financial fuel of most of the growth seen in most of the G-20 economies for nearly two generations was the flow of funds coming from larger public deficits and accessible private borrowing. While the threat of liquidity traps always loom out amidst such tactics, a number of troubling financial trends has fueled the creative destruction of global capitalism since the oil shocks and geopolitical impasses of the Nixon era. While many point to rapid globalization or technological innovation, the urge to splurge on borrowed money has remained the world's key economic resource. As Brenner observes,

It was only the turn to large-scale Keynesian federal deficits, accommodated by easy credit, which made possible the subsidies to demand that enabled the advanced capitalist economies to transcend the oil crisis recession of 1974-75 and to continue to expand during the remainder of the decade. As it would for the next two decades, the massive growth of debt--especially public debt, which enabled parallel increases in private borrowing--constituted the indispensable key to international economic stability and expansion. Since only the US government was able, and willing to sustain the ever larger budget deficits that turned out to be necessary--and the increased current account deficits that accompanied them--it was only US government borrowing that kept the world economy afloat during the following extended period of reduced private profitability and capital accumulation (Brenner, 2002: 33).

Here the conditions in the 1970s and 1980s were being created, and then sustained, to foster multitudes of NINJA subjects as well as deepen pockets of plutonomy. Who borrows from whom, how, when, and where fuels the wild growth of FIRE-based prosperity as well as the underemployment, joblessness, and asset stripping endured by NINJA subjects in an economy on FIRE.

During this same time frame, income disparities in the U.S.A. have grown far more pronounced as plutonomy grew. In 1970, the poor in the U.S.A. earned more than 10 percent of all income, and the "super rich" only earned 1 percent of all income. Actually, the poorest third of all Americans still received 10 times as much income as the richest .01 of 1 percent in the U.S.A. (Johnston, 2005: E1). During the next three decades, however, this balance shifted as the world witnessed a remarkable increase in plutonomic inequality.

By 2000, the 96 million wage earners at the bottom of America's class structure earned as much as only the top 28,000 super-rich individuals at the top of society. The poor's share of all income fell to 5 percent of all wage earnings, which was a 50 percent decrease, but the rich saw their share quintuple to more than 5 percent of all income. Adjusted for inflation between 1970 and 2001, the average 25 year old male wage earner--or a key household-forming economic agent in those days--in 1970 made the equivalent of \$2.00 more an hour than his counterpart in 2001 (Johnston, 2005: E1). The bottom 99 percent of all Americans from the very poor to the middle class saw an average increase in total income of only $\$ 2,710$--less than $\$ 100$ a year for all workers (or about 5 cents an hour raise per year for 30 years). Under these conditions, it is no surprise to see the NINJA subject becoming more multitudinous. The top 1 percent of the plutonomy at the same time, did much better. Their average annual household incomes rose from $\$ 20.3$ million to $\$ 24$ million from 1970 to 2001 (Johnston, 2005: E1).

By 2004, the average American CEO was taking home 300 times the average pay of ordinary workers, but in 1970 that spread had only been 30 times greater (The Economist, June 17, 2006: 30). These trends toward greater income and wealth inequalities were changing slowly in the 1970s, but they rapidly accelerated after 1980 . The share of aggregate income going to highest-earning 1 percent of Americans was 8 percent in 1980, but it had doubled to over 16 percent by 2004. In 1980, the top one-tenth of 1 percent of Americans took home 2 percent of all income in 1980, but the same fraction garnered 7 percent in 2004 (The Economist, June 17, 2006: 30). Even after the economic turmoil of 2007-2009, this figure rose further by 2010. The best, the super-rich, or the plutonomic interests, it would appear, have not been doing well by the rest, the non-rich, the NINJA multitudes--either in the U.S.A. or abroad. During 2009, even in the depths of the Great Recession, as the average income of most people slipped, the average income of the top five percent of earners still rose (Lieberman, 2011: 154). During 2009, the top ten percent of American households controlled nearly half of the nation's wealth, while the top 0.1 percent controlled about 10 percent of the country's wealth. Half a century before, the bottom 90 percent controlled 68 percent of the economy [http://money.cnn.com/2011/2/22/news/economy/income_inequality/index.htm?iid=EL].

In 2010, some in the U.S.A. look back at 1990 with satisfaction, because they witnessed then the demise of the U.S.S.R. and its state socialist alternatives to contemporary plutonomic American capitalism. Of course, as the Russian economy shrank to the size of the Netherlands with the Soviet Union's territorial fragmentation, industrial collapse, and economic stagnation, a few Russians have profited immensely through privatizing former 
state enterprises, acquiring control over natural resource markets or specializing in new forms of corruption in their own extraordinary "actually existing post-socialist plutonomy." Less often celebrated is the nearly coincidental implosion of "Japan, Inc.," which had threatened during the 1970s and 1980s to eclipse the U.S.A. as the world's largest economy by 2010. Instead Japan’s economy in 2010 is about the same size as it was in 1991-- \$5.7 trillion of GDP--and China has overtaken Japan as the second largest economy in the world (Fackler, 2010: W17). Meanwhile, the American economy has more than doubled in size from 1990-91 to 2010 with a $\$ 14.7$ trillion GDP. The past two decades have been tumultuous in the U.S.A. with many booms and busts; but, at the same time, plutonomic America has avoided the worst effects of economic stagnation or monetary deflation that have deformed the former Soviet Union and Japan.

Capitalism, then, can work well enough to not stop entirely as well as poorly enough to not grow effectively. As many marketplaces all around the world have seen for years, decades or generations, a truly efficient way forward to attain more gainful lives, fuller employment or quicker growth often proves evasive. Instead, the structural conditions of excess capacity, plentiful liquidity, high unemployment, rife underemployment, or slow to no organized growth characterizes many markets' exchange of goods and services. Capitalism does not actually end, but its manifest ends can become more elusive, empty, and then evil for many in the marketplace. That the last generation has ineptly misspent many years "sustaining" what has been taken as economic "development" in Russia and Japan only reinforces this point.

Markets are established to promote capital formation, wealth accumulation, long-term investment, and organized competition through mechanisms for the rational sale and purchase of commodities. With the automation of many exchanges, however, the behaviors of sellers and purchasers, minute pricing variations in stocks, bonds, commodities, FOREX, or derivatives, and the relative speed of transactional executions are creating moments of manipulation where and when electronic strategies tied to high-frequency algorithmic traders are making money only out of other money makers' real time behavioral performance patterns. Scanning price variations, measuring price differences between exchanges, and predicting future patterns in millisecond to minute measures begins to overshadow older modes of profit-seeking pegged to the standard market trading times of days, weeks, months, quarters, and years.

While such trading innovations have been justified in terms of increased profitability, efficiency, and service, they also are putting at risk most fungible assets and their markets. The average NASDAQ trade completes its roundtrip of order execution in 98 millionths of a second, but automated trading hubs are now under construction to attain transcontinental order execution speeds of 60 milliseconds (Bowley, 2011: BU1). Such accelerated liquidities provide new flows upon which plutonomy can more openly sail as well as more deeply dig the already ragged erosions in which the growing NINJA, and soon-to-be NINJA, classes must live.

\section{Blow Off: Predatory Professionalism?}

The plutonomic analysts' story line about the frightening collapse of America's once high-wage labor market tends to naturalize its inevitability and irreversibility by tying it to the allegedly relentless advance of technology (Luke, 1999). Consequently, a January 2010 Time magazine, for example, claims "the truth is that the decline in jobs is the result of megatrends including the growth of technology and the rise of globalization" (Karabell, 2010: 32). At the same turn, Time celebrates how "North Dakota's unemployment rate is 3.8\%, the lowest in the nation" (Saporito, 2010: 32) thanks to its technologically sophisticated mining, oil, gas, and energy industries and the ready buyers for those goods in India or China. Education and high-tech skills allegedly are the ticket to income, jobs, and assets. Yet, during 2010, December's 9.4 percent--down from 9.8 percent in November--official unemployment rate, those with some college training have an 8.7 percent rate of joblessness and those with a bachelor's degree or higher was 5.1 percent jobless. Taken together, these workers are experiencing an abnormally high level of unemployment (when 5 or 6 percent was once regarded as "normal") in the 1970s or 1990s (Saporito, 2010: 28-29).

What has been nearly forgotten in the bubble economy of the 2000 s is the complex and protracted "long downturn" in the major Western economies from 1973 to 1995, coming on the heels of the "long boom" of 1947 to 1973. Moreover, the past two decades also has seen the middle class being closed out of access to higher education as tuition increases, particularly at public universities has risen much faster than inflation. From 1988 to 2008 , tuition and fees increased 130 percent, while middle class incomes stagnated. To have kept this inflationary pace, family incomes in 2008 would have needed to be $\$ 77,000$ rather than $\$ 33,000$ annually. Student loans can, and have made 
up, this difference, but now many students graduate with up to 20 years of serious indebtedness to obtain degrees that once were far more accessible due to public support [http://money.cnn.com/2011/06/13/news/economy/ college_tuition_middle_class/index.htm?iid=Popular]. Indeed, "a long, debilitating stagnation held the US and the world economy firmly in its grip from the early 1970s right up to the middle 1990s, making for the snail-like growth of productiveness and declining living standards for more than a generation" (Brenner, 2002: 4). Floods of liquidity pumped into the market to mitigate the downside of the Asian currency crises, the big "dot.com" bust of 2000 as well as the mass panic triggered by the $9 / 11$ attacks in the U.S.A. are what restarted many businesses in the 2000 s.

A great deal of cheap money flooded into the market after the evisceration of the Glass-Steagall Act during the waning days of the Clinton administration. Alan Greenspan, Robert Rubin and Larry Summers, who were a Time magazine's 1999 cover trio tagged as "the Committee to Save the World," insured that high levels of liquidity poured into the economy to cope with the Long-Term Capital Management crisis, the Russian and Southeast Asian currency crises, various emerging country stock market and bank crashes, and, of course, the alleged Y2K computer system meltdown. For the feared Y2K crisis alone, the Fed dumped an extra $\$ 147$ billion into the American economy just in case ATMs or debit card machines did not work (Taibbi, 2010: G2). Of course, the Y2K collapse never happened, but the cash stayed in circulation.

By the turn of the century, Washington had put $\$ 1.7$ trillion additional dollars into the market that were not there five years before. From 2000 to 2004, Greenspan, in turn, encouraged consumers to get new home loans, tap into home equity, and step-up household consumption. After all, President Bush's clarion call to America after 9/11 boiled down to one goal--"go shopping" to support the "coalition of the willing" fighting to defeat "the Axis of Evil."

From the year Bush invaded Iraq in 2003 until the year after his election in 2004, the level of outstanding mortgage debt in the U.S.A. grew \$3.7 trillion. This level of added borrowing in 2003, 2004, and 2005 nearly equaled the market value of all American real estate at the end of the Cold War (or \$3.8 trillion) in 1990. At this key conjuncture, then, American consumers borrowed in nominal terms a sum that was nearly 200 years of accumulated savings, but much of it was done simply by riding on flows of newly printed dollars, repatriated fast money coming as dollar deposits from foreign lenders, or personal savings drawn-down from personal credit lines on existing home equity.

The Federal Reserve Bank had held interest rates flat or cut them from 2000 to 2004, and Alan Greenspan at the same time called upon the citizens of George W. Bush's "Opportunity Society" to use their home equity and/ or get adjustable mortgages in order to leverage this historic opportunity to "enrich themselves" (Taibbi, 2010: 71 72). Then the Fed commenced a rate increase drive in June 2004 that steadily moved rates up from 1 to 4.5 percent through 2006. Millions of borrowers had been lured into mortgages contracts with cheap money, easy home equity loans, and a vast supply of new housing stock rising across the Sunbelt states where everyone has been moving since 1945, but this rate tightening created a tremendous trap.

In their efforts to save the world, then, the eventualization of the recent American and world financial crisis was set. These conditions are not unlike how Foucault describes them, namely, "groups of elements where, in a totally empirical and temporary way, connections between mechanisms of coercion, maybe also legislative elements, rules, material set-ups, authoritative phenomena, etc." that acquires both "empirical observability" and "historical acceptability" as an ensemble of political economic, and legal choices (Foucault, 2007: 59, 61). The potential mechanisms for a severe crisis, therefore, eventualized themselves in years of ill-considered actual market decisions by both hapless NINJAs and predatory professionals both moving in search of profitable shelter and sheltered profit. The Federal Reserve's "frantic deregulation of the financial markets in the late nineties led directly to the housing bubble; in particular, the deregulation of the derivatives market had allowed Wall Street to create a vast infrastructure for chopping mortgage debt, disguising bad loans as AAA-rated investments, and selling the whole mess off on a secondary market as securities" (Taibbi, 2010: 73). As the January 2011 Financial Crisis Inquiry Commission report notes "The crisis was the result of human action and inaction, not of Mother Nature or computer models gone haywire'. . 'The captains of industry and public stewards of our financial system ignored warnings and failed to question, understand and manage evolving risks within a system essential to the well-being of the American public"” (Chan, 2011: A1).

From this vantage, the economic crisis of 2007-2009 is an excellent window for looking out on to "how actual relations of subjugation manufacture subjects" (Foucault, 1997: 45). For Alan Greenspan, advances in new computer technologies, better network connectivities, and more financial services created fabulous new opportunities: 
Technological advances have resulted in increased efficiency and scale within the financial services industry. . With these advances in technology, lenders have taken advantage of credit-scoring models and other techniques for efficiently extending credit to a broader spectrum of consumers (Greenspan cited in Taibbi, 2010: 73.

Such obviously bland declarations are important, because they indicate how relations of domination "assert themselves in their multiplicity, their differences, their specificity, or their reversibility," allowing one to observe "how the various operators of domination support one another, relate to one another, at how they converge and reinforce one another in some cases, and negate or strive to annul one another in other cases" (Foucault, 1997: 45).

In fact, the relations of juridico-legal subjugation via real estate ownership coupled with the technologies of fast financial intervention reinforced the social formations of plutonomics by creating new abject subjectivities, like the NINJA home occupant. These conditions created the actual relations of subjugation that remade subjects to the degree that real estate agents, builders, major consumer banks, and regulators could make "a jobless immigrant with no documentation and no savings into an AAA-rated mortgage risk" (Taibbi, 2010: 73). Before 2002, subprime loans (those borrowers with a credit score below 660) were less than $\$ 100$ billion of mortgages a year. Yet, in 2005, the new "technological innovations" celebrated by Alan Greenspan made it possible to lend out $\$ 600$ billion of subprime loans a year (Taibbi, 2010: 83). With opportunities like this, it is not surprising that such major sea changes in the economy allowed 65 percent of all income in the U.S.A. from 2002 to 2007 to flow increasingly to the top 1 percent of the population (Freeland, 2011: 48).

Furthermore, the crisis even now is not abating. Instead the NINJA subjects, as well as their barely solvent neighbors, are mired in mortgages greater than their home's worth, and stuck with houses in markets with falling values or neighborhoods with many vacant, unfinished or derelict homes. Many citizens and consumers typically are shackled by these arrangements of indebted servitude to just stay in place. About one-in-four homes with mortgages were "underwater" in July to September 2010 (18 of every 100 owe more than 110 percent of the home's presumed value) with about 30 percent in debt for 75 to 100 percent of their homes estimated value (Bialik, 2010: A4A).

During the two years running from September 2008 to September 2010, American households, or those, which had them, withdrew $\$ 311$ billion from their savings and investment accounts. This sum equals 1.4 percent of all disposable income, and it stands in marked contrast to trends during the prior six decades going back to the Truman administration. Until 2008, American households tended to add on average 12 percent of their disposable income every year to savings (Whitehouse, 2011). On one level, this drawdown represents those with some assets paying down expensive debt in lieu of receiving an essentially flat or negative rate of return on their money. Yet, on another level, this historic break also represents the American consumer using his or her own assets to cope with sudden unemployment, underemployment, and fringe benefit reductions/eliminations as the state and business sector have failed to create new jobs and eliminated collective benefits. At no other points in post-war U.S. history has this development occurred--the recessions of the late 1950s, early 1970s, the oil shocks of 1973 and 1979, the recessions after Reagan's George H. W. Bush or George W. Bush's elections in 1980, 1988 or 2000 all still saw aggregate household savings rise. By 2011, however, household wealth in the U.S.A. was still nearly $\$ 8$ trillion less than in 2006 despite the slight rebound in the stock market. The larger agendas of the plutonomic elites, then, are again being served as their directives dictate that one care for oneself only with one's own means and never count upon much decisive social assistance.

Undoubtedly, housing market trends and unemployment drove many to make these expenditures as millions struggle to prevent foreclosure on their homes. 2010 saw 1 million homes receiving actual foreclosures, and 2011 will probably see 1.2 million houses being repossessed nationwide (Roanoke Times, January 14, 2011: A8). States where the home-building craze was most extreme, like Nevada, California, Arizona, and Florida, and those where the industrial collapse was most pronounced, like Illinois or Michigan, have had double-digit rates of foreclosure as well as the greatest average housing price declines. Across the nation, 1 out of every 45 homes received a foreclosure notice, or 2.9 million overall (Roanoke Times, January 14, 2011: A8). Even though only one-third of those properties were repossessed in 2010, many more will undoubtedly be lost in 2011 as consumers exhaust their available savings and further housing price declines make refinancing difficult or impossible. While some banks appear willing to work out refinancing arrangements, or even let existing owners squat in the properties instead of abandoning them, many millions of homes are verging on foreclosure in 2011. Thus, the family home, which is the largest single asset most individuals have depended upon since the 1970s, as traditional defined benefit pension arrangements were trimmed back for nearly 80 percent of the work force, is being degraded and then destroyed for millions of households amidst the lingering gains for the nation's plutonomic elites. 
Greenspan's reifying thesis about technological innovations actually occludes more troubling realities in the U.S.A. Plutonomy in America does not track the outlines of a stable economy and society. Instead,

\begin{abstract}
Such a level of economic inequality, not seen in the United States since the eve of the Great Depression, bespeaks a political economy in which the financial rewards are increasingly concentrated among a tiny elite and whose risks are borne by an increasingly exposed and unprotected middle class. Income inequality in the United States is higher than in any other advanced industrial democracy and by conventional measures comparable to that in countries such as Ghana, Nicaragua, and Turkmenistan (Lieberman, 2011: 154-155).
\end{abstract}

The growth of plutonomy as well as its attendant inequality is not a normal product of the market. It is, to the contrary, a complex artificial construct that has been pieced together from the Nixon era to the Obama administration through a series of calculated policy decisions (Hacker and Pierson, 2010).

Eager to preserve their material embeddedness in these elaborate systems of positionally entrenched rentseeking, plutonomic experts appear to have developed at least three hedges against these technological innovations misfiring for them by leveraging the same speed, complexity, and volume of money flows that got so many new borrowers into the property markets. Thus, "the operators of domination" did indeed "support one another, relate to one another" with "these apparatuses of domination" rooted in fast money, excessive debt, and bad information. First, mortgage-issuing banks accelerated the securitization of these loans by pooling them in marketable multiples of promised steady, long-term steady return debt instruments, and then selling them for short-term profit to realize a faster time-value on their money. Mortgages pools with a potential fully amortized worth of $\$ 5$ million dollars would be sold off at a quick $\$ 3$ million, leaving others to collect the slow long term profits or suffer the medium-term defaults. Second, as the pools of good paper shrank, derivative instruments, like collateralized mortgage (or other debt) obligations, were devised to tier different grades of rated debt from AAA to junk with varying levels of higher return matched to lower quality rated debt. These two innovations could have worked well, but the lust for profits led many plutonomic interests to fudge factors with technology. Third, bundles of mortgages (or other debts) with high loan to value ratios, including some up with 99 percent loan to 1 percent equity, no borrower equity or collateral stake in the contracts, and no/low documentation of employment, credit, assets or residency were mixed into with good paper to provide just enough promise of profit to motivate many to make bad calls.

Truly effective risk analysis models, real credit histories or rational expectation transactions coupled with effective regulation would have long ago moved responsible experts to pull the plug on these financing packages, but most rating agencies in the U.S.A. did not. Instead they assigned many of these packaged CDO/CMO offers with a high percentage of AAA ratings. With interest rates on other credible investments so low, many desperate investors around the world jumped at such opportunities to profit from this blown off commercial churning. Thus, a full circuit of multiple, specific, and varied relations of domination in the U.S.A. activated both the NINJA nation and expansion of plutonomy through the degradation and/or destruction of savings at home and abroad.

Other devices for distorting markets, like "dark pool" trading, are supplementing these relatively more open financial strategies. Such transactions allow the traders to make exchanges without displaying the quotes for trades publicly within proprietary platforms and/or informal agreements that allow a few big operations to identity, count, price, and settle trades with front-run information. In effect, the participants in such pools are the owners, traders, and beneficiaries of the trading involved by simply managing all segments of the exchange electronically (Gorham and Singh, 2009). During the bubble economy of the 2000s, "the number of active dark pools dealing in stocks on major U.S. stock markets trebled to 29 in 2009 from about 10 in 2002” (Shunmugam, 2010). Such commerce is entirely a preserve of the new global elites who have the technological hardware, mathematical formulae, and entrenched market share to command such privileged powers over the market by making open free trade much more closed and constrained.

Indeed, society must be defended (Foucault, 1997). Yet, when the nation's economy rest upon plutonomics, then does it have to be developed by means, which essentially ensure that society must be defrauded? If so, there is much to learn from those who are the defrauded as well as those who are the defrauders. Exploring the social origins of professional-technical elite experts' near dictatorship over commerce or the foreclosed/bankrupted/dispossessed masses' frustrating experience with plutonomic democracy are important tasks. They should return us to foundational questions for the new class global elites in control of contemporary life, namely, "How does knowledge articulate power? What kind of power can be mediated through knowledge? Whose knowledge dominates whom. . How do class divisions and conflicts develop from unequal power and knowledge?” (Luke, 1999: ix). New class knowledges articulate powers for the new global elites, while today's class divisions and conflicts are developing from radically 
uneven distributions of unequal power and knowledge. In this case, the NINJA would-be home owner, the almost illiquid occupant of an underemployed job tied to sub-par rated companies, and the plutonomic global trader in liquid capital would appear to coinstantiate themselves as subjects of uncommon wealth and insolvent commonwealths in the apparatuses of domination channeling together so much of today's illiquid modernity as "economic growth."

During 1980, the average American C.E.O. earned 42 times as much as the average worker; but, by 2001, that figure had risen to 531 times as much. Not surprisingly, from 1980 to 2005, more than 80 percent of the total increase in Americans' overall incomes was gained by the wealthiest 1 percent of society (Kristof, 2010). In 2002, Kevin Phillips closed his Wealth and Democracy with a grim insight. The effects of great wealth on the shape and substance of American democracy since 1980 were becoming uncomfortably like the Gilded Age of the 1880s and 1890s. After two decades of Reaganism, he concluded:

\begin{abstract}
As the twenty-first century gets underway, the imbalance of wealth and democracy in the United States is unsustainable, at least by traditional yardsticks. Market theology and unelected leadership have been displacing politics and elections. Either democracy must be renewed, with politics brought back to life, or wealth is likely to cement a new and less democratic regime--plutocracy by some other name (Phillips, 2002: 422).
\end{abstract}

Nearly ten years later, the continuing crisis of economic excess, fiscal irresponsibility, and governmental restructuring has created a "lost decade" for all but a tiny minority of the wealthiest Americans. And, as economic dispossession, democratic degradation, and cultural corrosion spread across more and more communities in the U.S., Phillips appears to be proving correct. A new far less democratic regime is consolidating its plutocratic powers and privileges under the name of "plutonomics" in the U.S.A. as well as much of the more globalized world system organized around the greater production, prestige, and protection of monetary power for few at the expense of the many.

\title{
References
}

${ }^{*}$ Versions of this paper were prepared for the 2011 Telos Conference, New York University, January 16-17, 2011 and the annual meetings of the Global Studies Association, Loyola University-Chicago, May 20-22, 2011.

Balley, Martin Neil, Robert E. Litan and Matthew S. Johnson. 2008. The Origins of the Financial Crisis. Washington, DC: Brookings Institution.

Bialik, Carl. 2010. “Housing Statistics Hit Rough Waters," Wall Street Journal (January 8-9): A4A.

Bowley, Graham. 2011. “The New Speed of Money, Reshaping Markets," New York Times (January 2): BU1.

Brenner, Robert. 2002. The Boom and the Bubble: The U.S. in the World Economy. New York: Verso.

Chan, Sewell. 2011. "Financial Crisis was Avoidable, Inquiry Finds," New York Times (January 25): A1.

Fackler, Martin. 2010. “Japan Goes From Dynamic to Disheartened," New York Times (October 17): W17.

Foster, John Bellamy and Fred Magdoff. 2009. The Great Financial Crisis: Causes and Consequences. New York: Monthly Review Press.
Foucault, Michel. 2007. The Politics of Truth. New York: Semiotext(e).

Foucault, Michel. 1997. “Society Must be Defended.” New York: Picador.

Frank, Robert H. 2010. "Income Inequality: Too Big to Ignore," New York Times (October 18): B17.

Freeland, Chrystia. 2011. "The Rise of the New Global Elite," The Atlantic, 307, no. 1 (January-February): 45-57.

Fuentes, Nicola Lutes. 2009. "Defrauding the American Dream: Predatory Lending in Latino Communities and Reform of California's Lending Law," California Law Review, Vol. 79: 1279-1335.

Gorham, Michael and Nidhi Singh. 2009. Electronic Exchanges: The Global Transformation from Pits to Bits. Burlington, MA: Elsevier.

Hacker, Jacob S. and Paul Pierson. 2010. Winner-Take-All Politics: How Washington Made the Rich Richer--And Turned Its Back on the Middle Class. New York: Simon \& Schuster.

Johnston, David Cay. 2005. "Stroke the Rich," San Francisco Chronicle (April 11): E1. 
Kapur, Ajay, Nial Macleod, and Narendra Singh. 2005. Plutonomy: Buying Luxury, Explaining Global Imbalances. New York: Citigroup Research (October 16): 1-35.

Karabell, Zachary. 2010. "Where the Jobs Aren't," Time (January 17): 32 .

Kashkari, Neil and Steve Rodosky. 2011. "The Market Flashes 'Caution' on U.S. Treasuries,' Wall Street Journal (January 14): A15.

Kristof, Nicholas D. 2010. "Our Banana Republic," New York Times (November 7).

Krugman, Paul. 2011. “Deep Hole Economics," New York Times (January 2):

Lasch, Christopher. 1995. The Revolt of the Elites and the Betrayal of Democracy. New York: W. W. Norton.

Lasch, Christopher. 1991. The True and Only Heaven: Progress and Its Critics. New York: W. W. Norton.

Leonard, Andrew. 2010. “The United States of Inequality," Slate (September 28) [www.salon.com/technology/how_the_world_ works/2010/09/28/r\#ch_get_richer_poor_get_poorer].

Lieberman, Robert C. 2011. "Why the Rich are Getting Richer: American Politics and the Second Gilded Age," Foreign Affairs, 90, no. 1 (January-February): 154-158.
Lind, Michael. 2010. "Is America a Plutonomy?" Salon.com <http://www.salon.com/opinion/feature/2010/10/05/ lind_America_plutonomy>

Luke, Timothy W. 1999. Capitalism, Democracy, and Ecology: Departing from Marx. Urbana: University of Illinois Press.

Phillips, Kevin. 2002. Wealth and Democracy: A Political History of the American Rich. New York: Broadway Books.

Roanoke Times. 2011. "2011 to Top 2010 Record of 1 Million Home Forecloses” (January 14): A8.

Saporito, Bill. 2010. "Where the Jobs Are," Time (January 17): 26-35.

Shunmugam, Venkatachalam. 2010. "Dark Pools: The Menace of Rising Opacity in Financial Markets." Forbes (May 22) [http://blogsforbes.com/davos/2010/05/22/dark-pools-themenace-of-rising-opacity-in-financial-markets/]

Taibbi, Matt. 2010. Griftopia: Bubble Machines, Vampire Squids, and the Land Con that is Breaking America. New York: Spiegel \& Grau.

The Economist. 2006. "Special Report: Inequality in America," The Economist (June 17): 28-30.

Whitehouse, Mark. 2011. "Number of the Week: Americans Dipping into Savings," Real Time Economics: Wall Street Journal Blogs (January 22), [http://blogs.wsj.com/economics] 
